\title{
PENGARUH PEMBERIAN JUS MENTIMUN (Cucumis sativus L.) TERHADAP TEKANAN DARAH SISTOLIK DAN DIASTOLIK PADA PENDERITA HIPERTENSI
}

\author{
Lovindy Putri Lebalado, Tatik Mulyati*)
}

Program Studi Ilmu Gizi Fakultas Kedokteran Universitas Diponegoro

J1.Dr.Sutomo No.18, Semarang, Telp (024) 8453708, Email : gizifk@ undip.ac.id

\begin{abstract}
Background : Hypertension has been found to be the risk factor of cardiovascular disease and kidney disease. Men and women have the same potential in having hypertension. Food containing potassium and magnesium modified diet is one of complementary therapy to reduce blood pressure, one of them is cucumber. Cucumber is an example of vegetable that can be found easily in Indonesia, in which $100 \mathrm{~g}$ has $153 \mathrm{mg}$ potassium and $11 \mathrm{mg}$ magnesium.

Methods : This was an experimental study with control group pre-post test design. Subjects were 38 men and women with systolic blodd pressure $140 \leq 159 \mathrm{mmHg}$ and diastolic blood pressure between $90 \leq 99 \mathrm{mmHg}$. Recruited subjects were divided randomly into two groups. The intervention group receive $100 \mathrm{~g}$ of cucumber in juice form. Kolomogorov-smirnov was used to analyze normality, while paired t-test and Mann-Whitney test used to do statistical analyzes.

Results : Cucumber juice as much as $150 \mathrm{ml}$ in 7 days can decrease $12 \%$ of systolic $(P=0,000)$ and 10,4\% of diastolic $(P=0,000)$ blood pressure, respectively, while in control group there was $2 \%$ decrease of systolic blood pressure $(P=0,077)$ and $1,1 \%$ increase of diastolic blood pressure $(P=0,419)$, respectively.

Conclusions : Seven days consumption of $150 \mathrm{ml}$ cucumber juice can significantly reduce systolic and diastolic blood pressure in hypertensive men and women.

Key words: Cucumber juice, systolic blood pressure, diastolic blood pressure, hypertension.
\end{abstract}

\section{ABSTRAK}

Latar Belakang : Hipertensi merupakan faktor risiko terjadinya penyakit kardiovaskuler dan penyakit ginjal. Lakilaki dan perempuan memiliki risiko yang sama terhadap hipertensi. Asupan dengan modifikasi bahan makanan yang mengandung kalium dan magnesium menjadi salah satu terapi komplementer untuk menurunkan tekanan darah, salah satunya adalah mentimun. Mentimun merupakan sayuran yang tumbuh di segala musim dan mudah didapat di Indonesia dan memiliki kandungan kalium dan magnesium dalam $100 \mathrm{~g}$ sebanyak $153 \mathrm{mg}$ dan $11 \mathrm{mg}$.

Metode : Jenis penelitian ini adalah true experimental dengan rancangan control group pre-post test. Subjek sebanyak 38 orang terdiri dari laki-laki dan perempuan dengan tekanan darah sistolik 140 - $159 \mathrm{mmHg}$ dan diastolik 90 - 99 mmHg. Subyek kemudian dibagi menjadi 2 kelompok, yaitu kelompok kontrol dan perlakuan. Kelompok perlakuan mendapat jus mentimun yang menandung mentimun $100 \mathrm{~g}$ selama 7 hari. Uji normalitas menggunakan Kolmogorov-Smirnov dan analisis statisitik menggunakan uji paired t-test dan Mann-Whitney.

Hasil : Jus mentimun dengan dosis $150 \mathrm{ml}$ selama 7 hari dapat menurunkan tekanan darah sistolik dan diastolik sebesar 12\% $(P=0,000)$ dan 10,4\% (P=0,000), dibandingkan pada kelompok kontrol ada penurunan tekanan darah sistolik sebesar $2 \%(P=0,077)$ dan peningkatan tekanan darah diastolik 1,1\% $(P=0,419)$.

Kesimpulan : Konsumsi $150 \mathrm{ml}$ jus mentimun selama 7 hari dapat menurunkan tekanan darah sistolik dan diastolik pada laki-laki dan perempuan hipertensi secara signifikan.

Kata Kunci : Jus mentimun, tekanan darah sistolik, tekanan darah diastolik, hipertensi.

\section{PENDAHULUAN}

Hipertensi merupakan suatu kondisi dimana aliran darah secara konsisten memiliki tekanan yang tinggi pada dinding arteri. ${ }^{1,2}$ Diagnosis hipertensi ditegakkan apabila tekanan darah sistolik diatas $140 \mathrm{mmHg}$ dan diastolik diatas 90 mmHg. ${ }^{1,2}$ Ada dua macam hipertensi yaitu hipertensi esensial dan hipertensi sekunder. ${ }^{1}$ Hipertensi esensial adalah hipertensi yang tidak diketahui penyebabnya atau dengan kata lain merupakan hipertensi yang tidak didahului dengan penyakit lain dan mengambil porsi $90 \%$ dari seluruh kejadian hipertensi. ${ }^{3,4}$ Hipertensi merupakan faktor risiko terjadinya penyakit jantung koroner, stroke, infark miokardia, gagal jantung, dan penyakit ginjal. ${ }^{2,5}$ Wanita maupun pria memiliki risiko yang sama terhadap hipertensi. ${ }^{6}$

Berdasarkan profil Kesehatan Indonesia tahun 2009 prevalensi hipertensi sebesar 29,6\% dan meningkat menjadi $34,1 \%$ di tahun $2010^{7}$. Menurut profil kesehatan Jawa Tengah tahun 2012, prevalensi kejadian hipertensi adalah 1,64\% dengan kasus tertinggi ada di kota Semarang yaitu

\footnotetext{
${ }^{*}$ Penulis Penanggungjawab
} 
21.858 kasus $^{5,8}$ dengan $54 \%$ diantaranya memiliki usia 45-65 tahun. $^{8}$

Faktor-faktor yang mempengaruhi peningkatan tekanan darah adalah genetik, umur, jenis kelamin, etnis, obesitas, gaya hidup sedenter, dan asupan. ${ }^{9}$ Salah satu faktor risiko yang dapat dikelola adalah pengendalian asupan makanan. Modifikasi asupan bahan makanan yang mengadung kalium dan magnesium menjadi salah satu terapi komplementer untuk menurunkan tekanan darah, baik sistolik maupun diastolik. ${ }^{3}$ Rekomendasi asupan kalium dan magnesium menurut International Food Information Council Foundation dan North Carolina Dietetic Association untuk kalium 4700 mg dan magnesium $400 \mathrm{mg} .{ }^{12,1}$

Kalium dan magnesium berperan dalam memperbesar ukuran sel endotel, menghambat kontraksi otot halus pembuluh darah, menstimulasi produksi prostasiklin vasodilator dan meningkatkan produksi nitric oxide yang akan memicu reaksi dilatasi dan reaktivas vaskuler yang akan menurunkan tekanan darah. ${ }^{13,14}$ Kedua mikronutrien ini juga berpengaruh dalam sistem renin-angiotensin (RAS) yang merupakan pusat kontrol utama tekanan darah dan fungsi endokrin terkait kardiovaskuler. ${ }^{10}$ Kalium berperan dalam menghambat pelepasan renin dengan meningkatkan eksresi natrium dan air. ${ }^{15}$ Terhambatnya renin akan mencegah pembentukan angiotensin I dan II sehingga akan menurunkan sensitivitas vasokontriksi. ${ }^{15,10}$ Magnesium akan mempengaruhi stimulus di pusat saraf simpatetis agar vasokonstriksi tidak melewati batas yang dibutuhkan. ${ }^{14,16}$ Kalium dan magnesium dapat diperoleh dari sumber alami melalui sayuran dan buah-buahan. Sayuran yang dapat tumbuh disegala musim, mudah ditemui, dan banyak ditanam di Indonesia adalah mentimun.

Penelitian tentang pengaruh pemberian sumber kalium dari jus pepaya (270 gram), jus semangka (300 gram), dan jus melon (200 gram) yang setara dengan 500,2 mg kalium terhadap tekanan darah pada 47 subjek penderita hipertensi di Jawa Barat selama 5 hari, menunjukkan bahwa secara statistik terdapat penurunan yang signifikan terhadap tekanan darah sistolik pada kelompok perlakuan pepaya, semangka, dan melon masingmasing adalah sebesar $16,3 \mathrm{mmHg}, 18,50 \mathrm{mmHg}$, dan 14,67 mmHg. Begitu juga pada tekanan darah diastolik secara statistik terjadi penurunan yang signifikan pada kelompk perlakuan pepaya, semangka, dan melon masing-masing 12,44 $\mathrm{mmHg}, 12,69 \mathrm{mmHg}$, dan $10,3 \mathrm{mmHg} .{ }^{17}$
Penelitian lain di puskesmas daerah Pasuruan tentang pengaruh pemberian jus belimbing dan mentimun terhadap penurunan tekanan darah sistolik dan diastolik pada 28 orang dengan hipertensi esensial menyatakan bahwa pemberian jus belimbing dan mentimun dengan komposisi $70 \%$ dan $30 \%$ sebanyak 1 gelas $(200 \mathrm{ml})$ selama 14 hari, didapatkan angka penurunan yang signifikan pada tekanan darah sistolik sebesar 14,21 $\mathrm{mmHg}$ dan tekanan darah diastolik sebesar $11,36 \mathrm{mmHg}{ }^{18}$

Penelitian tentang pemberian sumber kalium dari jus mentimun kepada 20 lansia usia 65 tahun ke atas dengan hipertensi tanpa penyakit penyerta selama 5 hari di daerah Jombang, menyatakan bahwa perlakuan pemberian jus timun sebanyak 100 gram dalam 100cc air dapat menurunkan tekanan darah sistolik maupun diastolik secara signifikan yaitu $13 \mathrm{mmHg}$ dan 3 $\mathrm{mmHg}{ }^{19}$.

Berdasarkan uraian tersebut maka peneliti melakukan penelitian lebih lanjut tentang pengaruh jus mentimun (Cucumis sativus) terhadap tekanan darah sistolik dan diastolik pada penderita hipertensi.

\section{METODE PENELITIAN}

Penelitian ini merupakan penelitian true experimental dengan rancangan pre-post group design. $^{20}$ Variable bebas dalam penelitian ini adalah pemberian jus mentimundengan dosis $100 \mathrm{~g}$ dan variable terikatnya adalah tekanan darah sistolik dan diastolik penderita hipertensi. Pelaksanaan penelitian telah mendapat persetujuan dari Komite Etik Fakultas Kedokteran Universitas Diponegoro melalui terbitnya Ethical Clearance.

Subjek penelitian ini adalah karyawan dan karyawati Bappeda Provinsi Jawa Tengah dan Garuda Maintenance Facility - Aero Asia (GMFAA). Kriteria inklusi penelitian ini adalah termasuk dalam kategori hipertensi ringan yaitu memiliki tekanan darah sistolik 140 - $159 \mathrm{mmHg}$ dan/atau memiliki tekanan darah diastolik 90 - 99 $\mathrm{mmHg}$, berusia 25-55 tahun, berjenis kelamin lakilaki maupun perempuan, pada subjek perempuan belum mengalami menopause, tidak sedang mengonsumsi obat antihipertensi atau penurun tensi selama masa penelitian, memiliki riwayat hipertensi, tidak dalam keadaan sakit atau perawatan dokter berkaitan dengan penyakit jantung koroner, penyakit ginjal, maupun penyakit kronik lainnya, serta bersedia menjadi subjek penelitian dengan mengisi informed consent, dan dapat diajak berkomunikasi. 
Penentuan subjek dilakukan dengan metode conscutive sampling. Sebanyak 156 orang bersedia diperiksa tekanan darahnya untuk proses skrining awal dan diperoleh sebanyak 38 orang yang memenuhi kriteria inklusi penelitian. Subjek dibagi menjadi 2 kelompok dengan metode simple random sampling sehingga diperoleh 21 sampel pada kelompok perlakuan dan 17 sampel pada kelompok kontrol. Kelompok perlakuan mendapatkan jus mentimun sebanyak $150 \mathrm{ml}$ yang terdiri atas mentimun sebanyak 100 gram dengan kandungan kalium dan magnesium $153 \mathrm{mg}$ dan 11 $\mathrm{mg}^{29}$, ditambah air 50 dan ditambah sirup rendah kalori, sedangkan kelompok kontrol mendapatkan Air sirup rendah kalori sebanyak $150 \mathrm{ml}$.

Kelompok perlakuan dan kelompok kontrol masing-masing dilakukan selama 7 hari. Selama penelitian, asupan makan pada kelompok kontrol dan perlakuan tidak dikontrol dan dibiarkan sebagaimana biasa. Pencatatan makan dilakukan sehari sebelum perlakuan dan selama perlakuan dengan metode recall. Data asupan makan subjek dianalisis menggunakan program nutrisurvey 2007. Kepatuhan subjek mengonsumsi jus mentimun dicatat menggunakan formulir daya terima. Tidak ada subjek yang drop out dalam penelitian ini.
Tekanan darah sistolik dan diastolik satu jam sebelum dan satu jam setelah perlakuan diukur oleh perawat dengan menggunakan sphygmomanometer air raksa. Tekanan darah diambil dari lengan kiri dalam keadaan duduk, tenang, tidak dalam keadaan pasca beraktifitas, dan telapak tangan tidak mengepal. Pengambilan tekanan darah diambil sebanyak 2 kali dan diambil rata-ratanya.

Uji normalitas menggunakan uji Kolmogorov-Smirnov. Karakteristik subjek dianalisis dengan menggunakan analisis deskriptif. Perbedaan tekanan darah sistolik dan diastolik sebelum dan sesudah perlakuan kedua kelompok diuji dengan uji wilcoxon. Perbedaan pengaruh perlakuan kedua kelompok terhadap tekanan darah sistolik dianalisis menggunakan uji independent $t$ test dan uji Mann-whitney untuk tekanan darah diastolik.

\section{HASIL PENELITIAN \\ Karakteristik Subjek}

Karakteristik subjek yang terdiri dari gambaran umur, status gizi, jenis kelamin, serta tekanan darah sistolik dan diastolik subjek sebelum penelitian disajikan dalam tabel 1 .

Tabel 1. Karakteristik Subjek

\begin{tabular}{|c|c|c|c|c|c|}
\hline \multirow[t]{2}{*}{ Karakteristik Subjek } & \multicolumn{2}{|c|}{$\begin{array}{c}\text { Perlakuan } \\
(\mathbf{n}=21)\end{array}$} & \multicolumn{2}{|c|}{$\begin{array}{c}\text { Kontrol } \\
(n=17)\end{array}$} & \multirow[t]{2}{*}{$\mathbf{p}$} \\
\hline & $\mathbf{n}$ & $\%$ & $\mathbf{n}$ & $\%$ & \\
\hline \multicolumn{6}{|l|}{ Umur } \\
\hline 26-35 & - & - & 3 & 7,9 & \multirow{3}{*}{$0.488^{\mathrm{a}}$} \\
\hline $36-45$ & 3 & 7,9 & 3 & 7,9 & \\
\hline $46-55$ & 18 & 47,4 & 11 & 28,9 & \\
\hline \multicolumn{6}{|l|}{ Status Gizi } \\
\hline Normal $(18,5-22,9$ kg/m²) & 2 & 5,3 & 3 & 7,9 & \multirow{3}{*}{$0,419^{1}$} \\
\hline Overweight $\left(23-24,9 \mathrm{~kg} / \mathrm{m}^{2}\right)$ & 7 & 18,4 & 5 & 13,2 & \\
\hline Obesitas $\left(>25 \mathrm{~kg} / \mathrm{m}^{2}\right)$ & 12 & 31,6 & 9 & 23,7 & \\
\hline \multicolumn{6}{|l|}{ Jenis Kelamin } \\
\hline Laki-laki & 17 & $44,7 \%$ & 16 & $42,1 \%$ & \multirow{2}{*}{$0,239^{\mathrm{a}}$} \\
\hline \multirow[t]{2}{*}{ Perempuan } & 4 & $10,5 \%$ & 1 & $2,6 \%$ & \\
\hline & \multicolumn{2}{|c|}{ Perlakuan (Mean \pm SD) } & \multicolumn{2}{|c|}{ Kontrol (Mean \pm SD) } & $\mathbf{P}$ \\
\hline Tekanan Darah Sistolik & \multirow{2}{*}{\multicolumn{2}{|c|}{$\begin{array}{c}147,619 \pm 9,437 \\
90 \pm 5,477\end{array}$}} & \multirow{2}{*}{\multicolumn{2}{|c|}{$\begin{array}{c}144.706 \pm 5,145 \\
89.412 \pm 4,287\end{array}$}} & $0,134^{\mathrm{a}}$ \\
\hline Tekanan Darah Diastolik & & & & & $0,722^{\mathrm{a}}$ \\
\hline
\end{tabular}

Sebagian besar subjek dalam penelitian berusia antara 46-55 tahun, memiliki status gizi overweight dan obesitas, serta memiliki jenis kelamin laki-laki. Hasil uji beda terhadap umur, status gizi, dan jenis kelamin kelompok perlakuan maupun kontrol menunjukkan tidak ada perbedaan antara kedua kelompok ( $>0,05)$. Tidak ada perbedaan pada rerata tekanan darah sistolik dan diastolik pada kedua kelompok ( $p>0,05)$ 


\section{Asupan Makan Sebelum Intervensi}

Uji beda asupan makan antar kelompok dilakukan untuk mengetahui homogenitas subjek sebelum intervensi.

Tabel 2. Asupan makan sebelum intervensi

\begin{tabular}{lccc}
\hline & $\begin{array}{c}\text { Perlakuan }(\mathbf{n}=\mathbf{2 1}) \\
(\mathbf{M e a n} \mathbf{+} \mathbf{S D})\end{array}$ & $\begin{array}{c}\text { Kontrol }(\mathbf{n}=\mathbf{1 7}) \\
(\text { Mean } \pm \text { SD) }\end{array}$ & P \\
\hline Energi (kkal) & $1715,00 \pm 317,52$ & $1544,74 \pm 351,46$ & $0,126^{1}$ \\
Protein (g) & $61,91 \pm 13,99$ & $64,21 \pm 336.26$ & $0,660^{1}$ \\
Lemak Jenuh (g) & $16,15 \pm 5,64$ & $14,86 \pm 6,24$ & $0,347^{1}$ \\
Natrium (mg) & $1255,09 \pm 351,92$ & $1170,26 \pm 178,83$ & $0,054^{2}$ \\
Kalium (mg) & $1151,58 \pm 339,63$ & $1228,35 \pm 388,58$ & $0,895^{2}$ \\
Magnesium (mg) & $179,38 \pm 67,11$ & $178,59 \pm 42,07$ & $0,086^{1}$ \\
Serat (g) & $10,48 \pm 3,76$ & $8,56 \pm 2,89$ & $0.092^{1}$ \\
\hline
\end{tabular}

1. Uji beda independent t-test

2. Uji beda Mann-Whitney

Berdasarkan hasil pada tabel 2, tidak ada perbedaan asupan energi, protein, lemak jenuh, natrium, kalium, magnesium, dan serat antara kelompok perlakuan dan kontrol $(\mathrm{p}>0,05)$.

\section{Asupan Makan Selama Intervensi}

Asupan energi, protein, lemak jenuh, natrium, kalium, magnesium, dan serat dapat mempengaruhi tekanan darah sistolik maupun diastolik. Asupan makan subjek selama intervensi dapat dilihat pada tabel 3 .

Tabel 3. Asupan makan selama intervensi

\begin{tabular}{lccc}
\hline & $\begin{array}{c}\text { Perlakuan }(\mathbf{n}=\mathbf{2 1}) \\
(\text { Mean } \pm \text { SD) }\end{array}$ & $\begin{array}{c}\text { Kontrol }(\mathbf{n}=\mathbf{1 7}) \\
(\text { Mean } \pm \text { SD) }\end{array}$ & P \\
\hline Energi (kkal) & $1640,07 \pm 203,46$ & $1601.61 \pm 265,82$ & $0,612^{1}$ \\
Protein (g) & $60,54 \pm 9,01$ & $67.54 \pm 13.62$ & $0,066^{1}$ \\
Lemak Jenuh (g) & $16,82 \pm 5,05$ & $16,64 \pm 5,09$ & $0,917^{1}$ \\
Natrium (mg) & $1285,50 \pm 169,81$ & $1266,80 \pm 210.53$ & $0,607^{2}$ \\
Kalium (mg) & $1457,17 \pm 271,41$ & $1185,35 \pm 237,94$ & $0,003^{2}$ \\
Magnesium (mg) & $198,61 \pm 24,44$ & $177,15 \pm 53,91$ & $0,003^{1}$ \\
Serat (g) & $10,91 \pm 2,48$ & $10,24 \pm 2.32$ & $0,403^{1}$ \\
\hline
\end{tabular}

1. Uji beda independent t-test

2. Uji beda Mann-Whitney

Berdasarkan hasil uji beda, tidak ada perbedaan asupan energi, protein, lemak jenuh, natrium, dan serat antara kedua kelompok ( $p>0,05)$, namun terdapat perbedaan asupan kalium dan magnesium $(p<0,05)$. Adanya perbedaan asupan kalium dan magnesium dikarenakan adanya pemberian jus mentimun selama intervensi pada kelompok perlakuan.

Perubahan Asupan Makan Sebelum dan Selama Intervensi

Perubahan asupan makan sebelum dan selama intervensi antara kedua kelompok disajikan pada tabel 4.

Tabel 4. Perubahan asupan makan sebelum dan selama intervensi

\begin{tabular}{lccc}
\hline & $\begin{array}{c}\text { Perlakuan }(\mathbf{n}=\mathbf{2 1}) \\
(\text { Mean } \pm \text { SD) }\end{array}$ & $\begin{array}{c}\text { Kontrol }(\mathbf{n}=\mathbf{1 7}) \\
(\text { Mean } \pm \text { SD) }\end{array}$ & P \\
\hline Energi (kkal) & $-74.93 \pm 262.77$ & $56.87 \pm 380.11$ & $0,215^{1}$ \\
Protein (g) & $-1.36 \pm 12.76$ & $3,33 \pm 14,28$ & $0,291^{1}$ \\
Lemak Jenuh (g) & $0.66 \pm 2,54$ & $1,78 \pm 3,68$ & $0,386^{2}$ \\
Natrium (mg) & $30,41 \pm 444,19$ & $96,54 \pm 180,52$ & $0,569^{1}$ \\
Kalium (mg) & $303,59 \pm 193,10$ & $-1,03 \pm 96,19$ & $0,000^{1}$ \\
Magnesium (mg) & $43,34 \pm 37,37$ & $-1,44 \pm 60,64$ & $0,008^{1}$ \\
Serat (g) & $0,43 \pm 3,46$ & $1,68 \pm 3,80$ & $0,293^{1}$ \\
\hline
\end{tabular}

1. Uji beda independent t-test

2. Uji beda Mann-Whitney 
Berdasarkan tabel 4, tidak ada perbedaan perubahan asupan energi, protein, lemak jenuh, natrium, dan serat, namun terdapat perbedaan pada perubahan asupan kalium dan magnesium pada kelompok perlakuan.
Pengaruh Pemberian Jus Mentimun terhadap Tekanan Darah Sistolik dan Diastolik

Pengaruh pemberian jus mentimun terhadap tekanan darah sistolik dan diastolik disajikan dalam tabel 5 .

Tabel 5. Pengaruh Pemberian Jus Mentimun terhadap Tekanan Darah Sistolik dan Diastolik

\begin{tabular}{lccc}
\hline \multicolumn{1}{c}{ Variabel } & Perlakuan $(\mathbf{n = 2 1})$ & Kontrol $(\mathbf{n = 1 7})$ & \multirow{2}{*}{ P } \\
\cline { 2 - 3 } & Mean \pm SD & Mean \pm SD & \\
\hline Tekanan Darah Sistolik (mmHg) & & & \\
Pre Perlakuan & $147,619 \pm 9,437$ & $144,706 \pm 5,145$ & \\
Selama Perlakuan & $131,769 \pm 6.775$ & $141,849 \pm 3,703$ & \\
Besar Penurunan & $15,850 \pm 7,77$ & $2,857 \pm 6,66$ & $0.000^{1}$ \\
\% & 12 & 2 & \\
P & $0,000^{\mathrm{a}}$ & $0,077^{\mathrm{a}}$ & \\
\hline Tekanan Darah Diastolik (mmHg) & & & \\
Pre Perlakuan & $90 \pm 5,477$ & $89.412 \pm 4,287$ & \\
Selama Perlakuan & $81,545 \pm 4,757$ & $90,420 \pm 3,062$ & \\
Besar Penurunan & $8,455 \pm 6,19$ & $1,008 \pm 3,60$ & $0,000^{1}$ \\
\% & 10,4 & $-1,1$ & \\
P & $0,000^{\mathrm{a}}$ & $0,419^{\mathrm{a}}$ & \\
\hline
\end{tabular}

a Uji beda wilcoxon

1.Uji independet t-test

Hasil uji beda pada tabel 5 menunjukkan adanya perbedaan tekanan darah sistolik dan diastolik yang bermakna pada sebelum dan selama perlakuan $(\mathrm{P}<0,05)$, sedangkan tekanan darah sistolik dan diastolik pada kelompok kontrol tidak mengalami perubahan bermakna $(\mathrm{P}>0,05)$.
Penurunan yang terjadi pada kelompok perlakuan adalah sebesar $12 \%$ untuk tekanan darah sistolik dan $10,4 \%$ untuk diastolik.

Pengaruh Pemberian Jus Mentimun terhadap Tekanan Darah Sistolik dan Diastolik Kelompok Perlakuan dan Kontrol

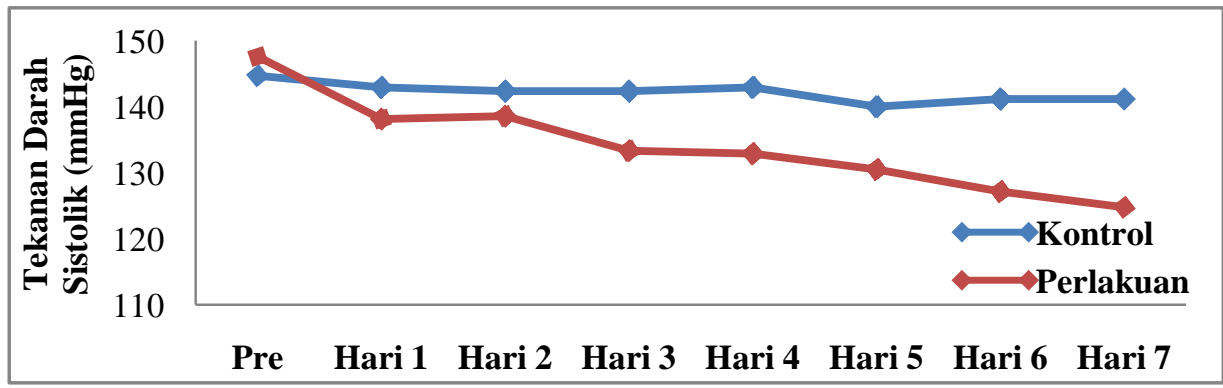

Gambar 1. Perubahan Tekanan Darah Sistolik Selama Intervensi

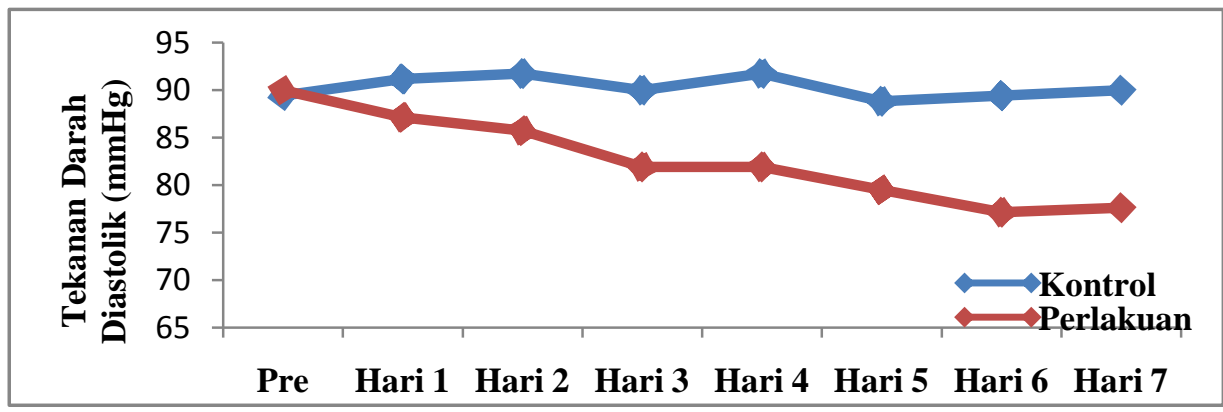

Gambar 2. Perubahan Tekanan Darah Diastolik Selama Intervensi 
Gambar 1 menunjukkan perubahan tekanan darah sistolik sebelum dan selama intervensi. Terlihat bahwa penurunan pada kelompok perlakuan terjadi lebih besar pada hari ke-1, tetap pada hari ke-2, kemudian turun secara bertahap mulai dari hari ke-3 sampai hari ke-7. Pada kelompok kontrol terjadi penurunan pada hari ke-1, sedangkan hari ke-2 sampai hari ke-7 cenderung fluktuatif dengan nilai yang tidak jauh berbeda. Gambar 2 menunjukkan perubahan tekanan darah diastolik sebelum dan selama intervensi Dapat dilihat penurunan pada kelompok perlakuan terjadi secara bertahap. Penurunan paling besar ada pada hari ke-3, sedangkan ada peningkatan sedikit pada hari ke-4 dan ke-7. Pada kelompok kontrol, tekanan darah diastolik cenderung menitngkat, tetapi terjadi penurunan pada hari ke-3 dan ke-5.

\section{PEMBAHASAN}

Karakteristik subjek dalam penelitian ini sebagian besar berjenis kelamin laki-laki, berusia 46-55 tahun dengan status gizi overweight dan obesitas. Sehingga dapat disimpulkan bahwa karakteristik subjek pada penelitian ini sudah sesuai dengan faktor yang dapat meningkatkan risiko hipertensi.

Risiko hipertensi semakin bertambah setelah usia 40 tahun. $^{21}$ Hal ini terjadi akibat perubahan struktur pada pembuluh darah besar yang mengakibatkan penyempitan lumen dan pengurangan sifat vaskositas dan elastisitas pembuluh darah. ${ }^{21}$ Gambaran status gizi juga menjadi salah satu faktor yang mempengaruhi tekanan darah. Menurut Institut Kesehatan Nasional Amerika (NIH), status gizi obesitas meningkatkan risiko hipertensi menjadi dua sampai enam kali lipat. ${ }^{2}$ Penimbunan lemak viseral maupun di jaringan adiposa dapat memicu Angiotensin II memproduksi stress oksidatif, faktor pro-inflamatory, dan memicu pelepasan sitokin yang menyebabkan disfungsi endotelial dan inflamasi vaskuler. ${ }^{22}$

Tekanan darah sistolik dan diastolik serta asupan makan subjek sebelum intervensi pada kedua kelompok tidak menunjukkan perbedaan yang bermakna. Angka kecukupan kalium yang dianjurkan menurut AKG 2013 adalah 4700 mg, angka ini sama dengan yang dikemukakan oleh International Food Information Council Foundation. ${ }^{23,12}$ Kecukupan magnesium menurut AKG 2013 untuk laki-laki adalah 350 mg dan 320 mg untuk perempuan. ${ }^{23}$ Rerata asupan kalium subyek sebelum intervensi adalah sebesar $1152 \mathrm{mg}$ untuk kelompok perlakuan dan $1228 \mathrm{mg}$ untuk kelompok kontrol. Setelah diberikan intervensi, rerata asupan kalium pada kelompok perlakuan meningkat secara bermakna menjadi $1457 \mathrm{mg}$. Nilai ini memenuhi $31 \%$ dari angka kecukupan. Pada kelompok kontrol, asupan kalium sebelum intervensi adalah $1228 \mathrm{mg}$ dan menurun menjadi $1185 \mathrm{mg}$ selama perlakuan.

Rerata asupan natrium subyek kelompok perlakuan dan kontrol sebelum intervensi adalah $1255 \mathrm{mg}$ dan $1170 \mathrm{mg}$. Selama perlakuan, asupan natrium pada kelompok perlakuan dan kontrol sama-sama meningkat, yaitu $1286 \mathrm{mg}$ pada kelompok perlakuan dan $1266 \mathrm{mg}$ pada kelompok kontrol. Bila dibandingkan, rasio asupan kalium : natrium pada kelompok perlakuan adalah $0,7: 1$, pada kelompok kontrol rasio yang terjadi adalah $0,6: 1$. Dapat dilihat bahwa rasio kalium pada kelompok perlakuan lebih tinggi daripada kelompok kontrol. Jika dikaitkan dengan selisih penurunan tekanan darah sistolik, penurunan lebih besar terjadi pada kelompok perlakuan. Hal ini mungkin disebabkan oleh rasio kalium yang lebih besar daripada kelompok kontrol, namun tidak jauh berbeda. Oleh karena itu, penurunan juga terjadi pada kelompok kontrol namun tidak bermakna.

Kemampuan kalium dalam mengurangi sensitifitas norepinefrin dan angiotensin II, meningkatkan natriuresis, memperbesar ukuran sel endotelial vaskuler, mengurangi kekakuan pembuluh darah, dan mempertahankan fungsi sel endotelial dengan meningkatkan produksi nitric oxide (NO) berpengaruh terhadap penurunan tekanan darah sistolik maupun diastolik. ${ }^{3,11,13,15}$ Penelitian tentang pengaruh pemberian kalium secara bertahap dari $2 \mathrm{mmol}$ sampai $8 \mathrm{mmol}$ pada kultur jaringan endotelial sapi, menunjukkan bahwa peningkatan asupan kalium berbanding lurus dengan ukuran sel endotel dan dapat mengurangi kekakuan sel endotelial. ${ }^{13}$

Homeostasis natrium dan kalium memainkan peran penting dalam vasodilatasiterkait-endotelium. ${ }^{15}$ Keadaan hipertensi menyebabkan peningkatan sekresi renin dan aktifasi RAS menjadi tidak bisa dikendalikan. Kalium berperan dalam meningkatkan sensitifitas syaraf simpatetik sehingga pengeluaran renin dapat dicegah. Selain itu, asupan kalium dalam jumlah cukup dapat mengurangi retensi natrium dan cairan.

Rasio asupan kalium dan natrium juga memiliki peran penting dalam kontrol tekanan darah. ${ }^{15,24}$ Efek penurunan tekanan darah sistolik 
pada kalium bekerja paling maksimal ketika asupan natrium juga tinggi, dibandingkan pada asupan natrium rendah. ${ }^{24,25,26}$ Eksresi natrium dan rasio kalium-natrium berpengaruh secara signifikan terhadapt tekanan darah sistolik dan diastolik pada asupan natrium lebih dari $6 \mathrm{~g} / \mathrm{hari}^{26}$ Rasio asupan kalium-natrium yang dianjurkan adalah 5:1 dimana jumlah kalium dan natrium yang dianjurkan adalah $120 \mathrm{mmol} / \mathrm{hari}(4700 \mathrm{mg})$ dan $60 \mathrm{mmol} / \mathrm{hari}(1500 \mathrm{mg}){ }^{15}$ Konsumsi kalium diatas 120 mmol tidak memberikan efek bermakna pada tekanan darah.

Asupan magnesium subyek sebelum intervensi kelompok perlakuan dan kelompok kontrol adalah $179 \mathrm{mg}$. Setelah intervensi selama 7 hari, didapatkan rerata asupan magnesium pada kelompok perlakuan meningkat menjadi $199 \mathrm{mg}$, sedangkan pada kelompok kontrol turun menjadi 177 mg. Pada kelompok perlakuan, asupan magnesium sudah memenuhi 57\% kebutuhan berdasarkan AKG 2013.

Magnesium mempengaruhi tekanan darah dengan memodulasi reaktivitas dan pergerakan vaskuler. Selain itu magnesium juga beperan dalam memproduksi prostasiklin vasodilator dan nitric oxide. ${ }^{14}$ Namun mekanisme lebih lanjut pengaruh magnesium terhadap tekanan darah masih diteliti lebih lanjut karena pada penelitian yang menguji suplementasi $184 \mathrm{mg}$ magnesium dua kali sehari pada 14 subjek laki-laki normomagnesemik menunjukkan tidak ada penurunan tekanan darah sistolik dan diastolik yang bermakna. ${ }^{27}$ Hasil yang berbeda didapatkan pada eksperimen suplementasi $450 \mathrm{mg}$ magnesium pada 42 subyek hipertensi dengan hipomagnesemik dapat menghasilkan penurunan tekanan darah sistolik dan diastolik yang signifikan $(20,4 \mathrm{mmHg}$ dan $8,7 \mathrm{mmHg}){ }^{28}$ Penyebab terjadinya penurunan ini diduga akibat mekanisme calcium channel antagonist dan penghambatan kerja angiontensi II yang berakibat pada pencegahan sekresi norepinefrin. Selain itu suplementasi magnesium oral akan bekerja lebih baik pada peningkatan aktivitas plasma renin. ${ }^{28}$ Untuk mengontrol tekanan darah, asupan magnesium yang disarankan adalah 400 $\mathrm{mg} /$ hari. $^{1,24}$

\section{SIMPULAN}

Pemberian jus mentimun dengan dosis 150 $\mathrm{ml}$ (kalium $153 \mathrm{mg}$ dan magnesium $11 \mathrm{mg}$ ) setiap hari selama 7 hari berpengaruh secara bermakna terhadap penurunan tekanan darah sistolik dan diastolik pada pria dan wanita dengan hipertensi ringan. Ada perbedaan tekanan darah sistolik dan diastolik antara kelompok kontrol dan perlakuan.

\section{SARAN}

1. Penderita hipertensi ringan (tekanan darah sistolik 140 - $159 \mathrm{mmHg}$, tekanan darah diastolik $90 \quad-99 \mathrm{mmHg}$ ) dapat mengkonsumsi jus mentimun sebagai salah satu sumber kalium dan magnesium tambahan untuk memenuhi kebutuhan kalium dan magnesium harian dan sebagai makanan alternatif maupun komplementer dengan jenis makanan lain dalam menurunkan tekanan darah sistolik dan diastolik dengan dosis minimal $150 \mathrm{ml} / \mathrm{hari}$.

2. Penelitian lebih lanjut perlu dilakukan untuk melihat apakah asupan kalium yang lebih mendekati angka kecukupan dapat berpengaruh lebih besar dalam penurunan tekanan darah.

3. Tekanan darah dapat terkontrol lebih baik apabila ditunjang dengan perbaikan pada faktor resiko lain, seperti berat badan, pengurangan asupan lemak jenuh, dan memenuhi asupan kalori sesuai kebutuhan.

4. Perlu adanya pemberian konsultasi secara mendalam mengenai pentingnya asupan makanan yang tinggi kalium dan magnesium, dan pengurangan makanan tinggi natrium dalam rangka menanamkan kebiasaan sehat yang dapat membantu dalam penurunan tekanan darah.

\section{DAFTAR PUSTAKA}

1. Mahan, L.K., Escott-Stump, S., Raymond, J.L. Krause's Food and the Nutrition Care Process. 13th edition. Missouri: Elsevier Saunders, 2012.

2. Chobanian A. V., et al. The Seventh Report of th Joint National Commitee on Prevention, Detection, Evaluation, and Treatment of High Blood Pressure. JAMA 2003;289:2560-2572.

3. Sacks F.M., Campos H. Dietary Therapy in Hypertension. N Engl J Med 2010:362:2102-12.

4. Nelms M. et al. Nutrition Therapy and Pathophysiology 2/e. Wadsworth : Cengage Learning, 2011.

5. Profil Kesehatan Jawa Tengah 2012. Dinas Kesehatan Provinsi Jawa Tengah.

6. Riset Kesehatan Dasar 2007. Departemen Kesehatan Republik Indonesia. Desember 2008.

7. Kemenkes RI. Profil Kesehatan Indonesia tahun 2009 dan 2010. Jakarta: Kemenkes RI, 2011.

8. Profil Kesehatan Kota Semarang tahun 2012. Dinas Kesehatan Kota Semarang.

9. Singh R. B., et al. Prevalence and Risk Factors for Prehypertension an Hypertension in Five Indian 
Cities. Acta Cardiol 2011, 66(1): 29-37. DOI: 10.2143/AC.66.1.2064964.

10. Drenjančević-Perić I., Jelaković B., Lombard J.H., Kunert M.P., Kibel A., Gros M. High-Salt Diet and Hypertension: Focus on the ReninAngiotensin System. Kidney Blood Press Res 2011;34:1-11. DOI: 10.1159/000320387.

11. He, F.J., et al. Effects of Potassium Chloride and Potassium Bicarbonate on Endothelial Function, Cardiovascular Risk Factors, and Bone turnover in Mild Hypertensives. Hypertension. 2010;55:681-688; 10.1161/HYPERTENSIONAHA .109.147488.

12. International Food Information Council Foundation Fact Sheet. Potassium and Heart Health. April 2011.

13. Oberleithner H., Callies C., Kusche-Vihrog K., Shahin V., Riethmü Iller C., MacGregor G.A., de Wardener H. E. Potassium Softens Vascular Endothelium and Increases Nitric Oxide Release. 2009. DOI: 10.1073 pnas.0813069106.

14. Sontia B, Touyz RM: A role of magnesium in hypertension. Arch Bioch Biophys 458:33. 2006.

15. Houston M.C. The Importance of Potassium in Managing Hypertension. 2011. Curr Hypertens Rep. DOI: 10.1007/s11906-011-1097-8.

16. Gropper SS., Smith JL., Groff JL. Advance Nutrition and Human Metabolism. 5th edition. 2009. Cengage Learning. Wadsworth, Belmont. California.

17. Mariani E. Pengaruh Pemberian Jus Pepaya (Carica papaya), Jus Semangka (Citrullus vulgaris), dan Jus Melon (Cucumis Melo) terhadap Penurunan Tekanan Darah Sistolik dan Diastolik. Program Studi Ilmu Gizi Fakultas Kedokteras Universitas Diponegoro. Semarang. 2007.

18. Muniroh L., Wirjatmadi B., Kuntoro. Pengaruh Pemberian Jus Buah Belimbing dan Mentimun terhadap Penurunan Tekanan Darah Sistolik dan Diastolik Penderita Hipertensi. The Indonesian Journal of Public Health, Vol. 4, No. 1, Juli 2007: 25-34.

19. Kusnul Z., Munir Z. Efek Pemberian Jus Mentimun terhadap Penurunan Tekanan darah. Universitas Pesantren Tinggi Darul 'Ulum. Jombang. 2012.

20. Sastroasmoro, S., Ismael, S. Dasar-dasar Metodologi Penelitian Klinis Edisi ke-4. 2011. Jakarta: CV. Sagung Seto.

21. Rahajeng E., Tuminah S. Prevalensi Hipertensi dan Determinannya di Indonesia. Pusat Penelitian Biomedis dan Farmasi Badan Penelitian Kesehatan, Departemen Kesehatan RI, Jakarta. Desember 2009

22. Savoia C., Schiffrin E. Vascular Inflammation in Hypertension and Diabetes: Molecular Mechanism and Therapeutic Interventions. Clin Sci (London)112:375, 2007.
23. Angka Kecukupan Gizi (AKG) 2013.

24. Appel, L.J. ASH Position Paper: Dietary Approaches to Lower blood Pressure. J Clin Hypertens (Greenwich) 2009;11:358-368.

25. Aburto, N.J., Hanson, S., Gutierrez, H., Hooper, L., Elliot, P., Cappuccio, F.P. Effect of increased potassium intake on cardiovascular risk factors and disease: systematic review and meta-analyses. BMJ 2013;346:f1378 doi: 10.1136/bmj.f1378.

26. Rodrigues, S.L., Baldo, M.P., Machado, R.C., Forechi, L., Molina, M. dC. B., Mill, J.G. High potassium intake blunts teh effect of elevated sodium intake on blood pressure levels. Journal of the American Society of Hypertension 8(4) (2014) 232-238.

27. Cosaro, E., Bonafini, S., Montgana, M., Danese, E., Trettene, M.S., Minuz, P., Delva, P., Fava, C. Effects of magnesium supplements on blood pressure, endothelial fuction and metabolic parameters in healthy young men with a family history of metabolic syndrome; A randomized crossover trial. Nutrition, Metabolism, and Cardiovascular Disease (2014), doi: 10.1016/j.numecd.2014.05.010.

28. Guerrero-Romero, F., Rodríguez-Morán, M. The effect of lowering blood pressure by magnesium supplementation in diabetic hypertensive adults with low serum magnesium levels: a randomized, double-blind, placebo-controlled clinical trial. Journal of Human Hypertension (2009) 23, 245251.

29. National Nutrient Database for Standard Reference, Nutrient Data No. 11205, USDA. 